\title{
2. TYPES AND SOURCES OF LARGE ROCK CLASTS AND OF HEAVY MINERALS FROM ODP SITES 652, 653, 654, AND 656 IN THE TYRRHENIAN SEA: IMPLICATIONS ABOUT THE NATURE OF THE EAST SARDINIA PASSIVE CONTINENTAL MARGIN ${ }^{1}$
}

\author{
R. Sartori, ${ }^{2}$ G. Mascle,${ }^{3}$ J. P. Bouillin, ${ }^{4}$ J. Girault,${ }^{3}$ G. Naud,${ }^{5}$ M. Pasini,${ }^{6}$ and M. Piboule ${ }^{4}$
}

\begin{abstract}
Analyses of rock clasts and of heavy minerals in upper Miocene coarse detrital units drilled along the East Sardinia passive-type continental margin (Sites $654,653,652$, and 656 ) reveal that the stretched basement contains quite complex rock suites. Taking also into account previous sampling data, in moving from west to east across the margin, the nature of the basement changes drastically.

To the west there are mostly Hercynian basement rocks with their cover, referable to the alpine foreland of the Corsica-Sardinia block. To the east, along the lower margin, where crustal thinning is quite severe, the basement contains rock suites referable to a pre-upper Tortonian orogenized zone with units constituting parts of the Alpine and Apenninic chains (presumably with thickened continental crust prior to stretching). Largest thinning and ocean forming occurred then, in a rather short time, mostly at the expense of unstable crust just thickened by orogenetic/tectogenetic processes.
\end{abstract}

\section{INTRODUCTION}

Rock fragments deriving from the nonvolcanic acoustic basement of the Tyrrhenian Sea were recovered during ODP Leg 107 at Sites $652,653,654$, and 656 across the east Sardinia passivetype margin (Fig. 1). They are sedimentary, metamorphic, and igneous lithotypes of various ages and structural pertinence deriving from a continental margin deformed by stretching since upper Tortonian times (Kastens, Mascle, et al., 1987).

This paper describes in some detail the main recovered lithologies, in part preliminarily reported by Mascle, Sartori, et al. (1986), and tries to correlate them to the different structural domains encircling the Tyrrhenian Sea (as synthesized for instance by Sartori et al., 1987). Hole results will be described from west to east (Sites 654-653-652-656), that is, in the sense of progressive thinning of the margin from its upper portion to the lower one at the boundary with oceanic crust. In the same sense, crustal thickness decreases from some $20-25 \mathrm{~km}$ to less than 10 km (Recq et al., 1984).

\section{Site 654 (upper Sardinia margin)}

Rock fragments of the acoustic basement are contained in the lithologic Units 5 and 6 which, although undated, are overlain by deep-water nannofossil oozes of upper Tortonian age and are interpreted as the basal elements of a transgressive sequence of the same age (Kastens, Mascle, et al., 1987).

\section{Lithologic Unit 6}

Conglomerates interbedded with reddish gravel-bearing mudstones have been encountered from $415.7 \mathrm{mbsf}$ downward to the bottom of the hole $(478.3 \mathrm{mbsf})$. They are interpreted as syn-rift alluvial fan deposits marking the initial dissection by stretching of the upper Sardinia margin, and can be regarded as equivalents of the "postorogenic" Terravecchia Formation and of the

\footnotetext{
${ }^{1}$ Kastens, K. A., Mascle, J., et al., 1990. Proc. ODP, Sci. Results, 107: College Station, TX (Ocean Drilling Program).

2 Dipartimento Scienze Geologiche Università, via Zamboni 67, 40127 Bologna, Italy.

${ }^{3}$ Institut Dolomieu, Univ. Scient. Médicale, Grenoble, France.

${ }^{4}$ Laboratoire Géologie Alpine, Grenoble, France.

${ }^{5}$ Musée de la Ville, Pribas, France.

${ }^{6}$ Dipartimento Scienze della Terra Università, Siena, Italy.
}

base of the "Sahelian cycle" known on land (Borsetti et al., this volume). Rock clasts of this unit are essentially of two types.

\section{Metasedimentary Rocks}

Most samples are marbles showing a high degree of transformation and, sometimes, iso-orientation (Fig. 2); there are however also low-grade quartz-phyllitic lithotypes. Some thin sections show large calcitic crystals resulting possibly from transformation of crinoidal segments; other display microcrystalline fabric with red iron oxide partings, possibly recalling former deep-water carbonate facies (Fig. 3).

\section{Nonmetamorphic Carbonate Rocks}

A few specimens are made of bioclastic/micritic limestone only partly affected by pressure-solution cleavage and by diffuse microfracturing systems, without important recrystallization. They contain crinoidal fragments, brachiopods, and abundant foraminifers (Fig. 4) including Ophthalmidium, Glomospirella, and Meandrospirae which indicate an alpine facies of lower Triassic (Scythian) age.

\section{Lithologic Unit 5}

Greenish sandstones, with large shallow-water biogenic remains, overlie the previous conglomerates of Unit 6 from 403.9 to 415.7 mbsf. They contain an important terrigenous fraction made by low-grade metamorphic rocks, small amounts of quartz, feldspars, micas, and heavy minerals (Borsetti, et al., this volume) (Fig. 5).

\section{Heavy Minerals}

Heavy mineral distribution (Table 1) has been determined for three samples from Unit 5 and one sample from Unit 2, that is, interbedded gypsum and carbonate layers of Messinian age. They are characterized by the association of garnet (two different types, with a relative abundance of colorless garnet), chlorite, zircon, and opaque minerals. Muscovite is also present in small amounts, apatite is rare, epidote occurs as trace, and staurolite and chloritoid are absent.

\section{Source of Rock Clasts and of Heavy Minerals}

Clasts of Unit 6 derive from the immediate acoustic basement of the site. The metamorphic lithologies, including the former crinoidal limestones, are referable to lower-middle $\mathrm{Pa}$ - 


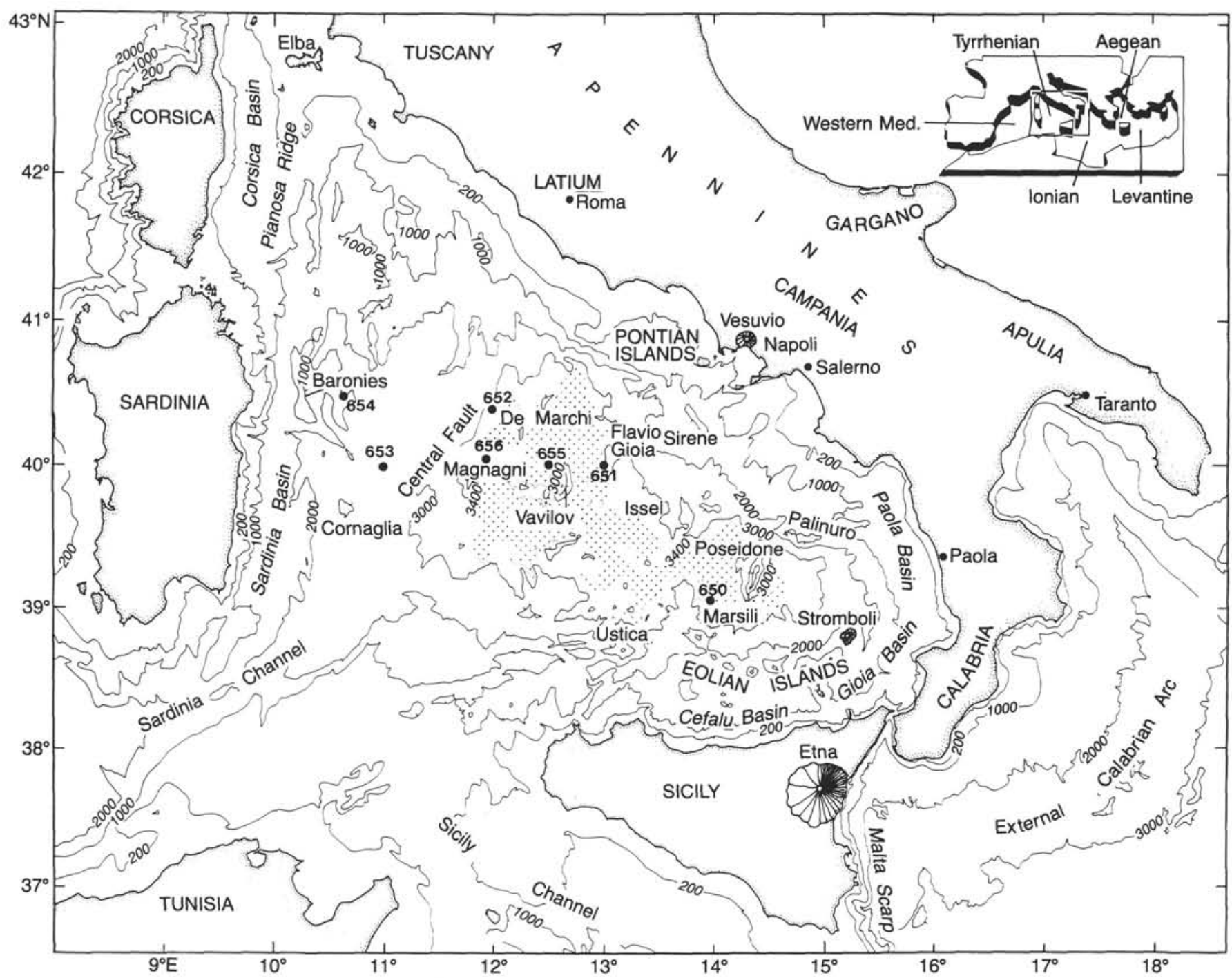

Figure 1. Schematic map of the Tyrrhenian Sea with location of the studied ODP Leg 107 Holes and of the main localities quoted throughout the text (modified after Kastens, Mascle, et al., 1987).

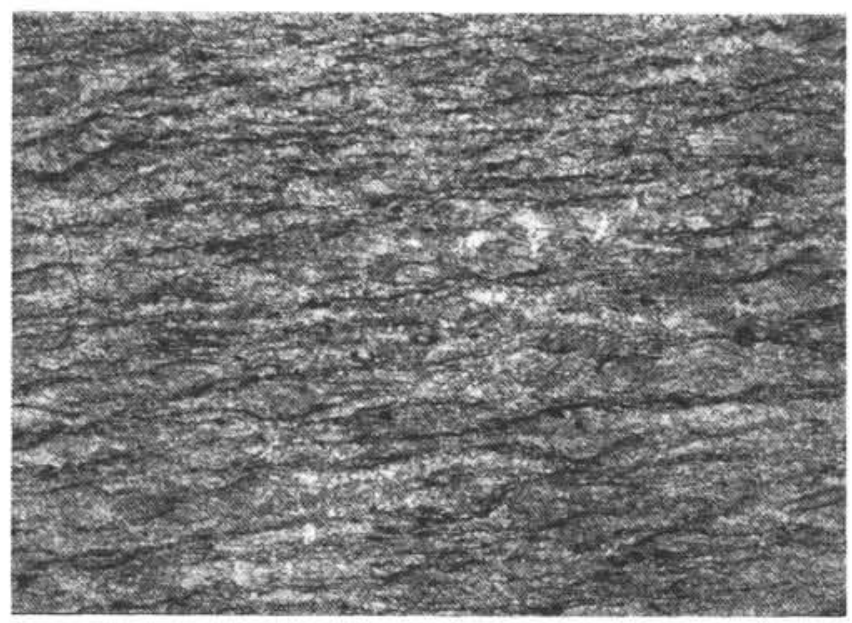

Figure 2. Marbles with severe iso-orientation. Sample 654A-50R-1, 26$29 \mathrm{~cm}$, polarized light, $16 \mathrm{X}$.

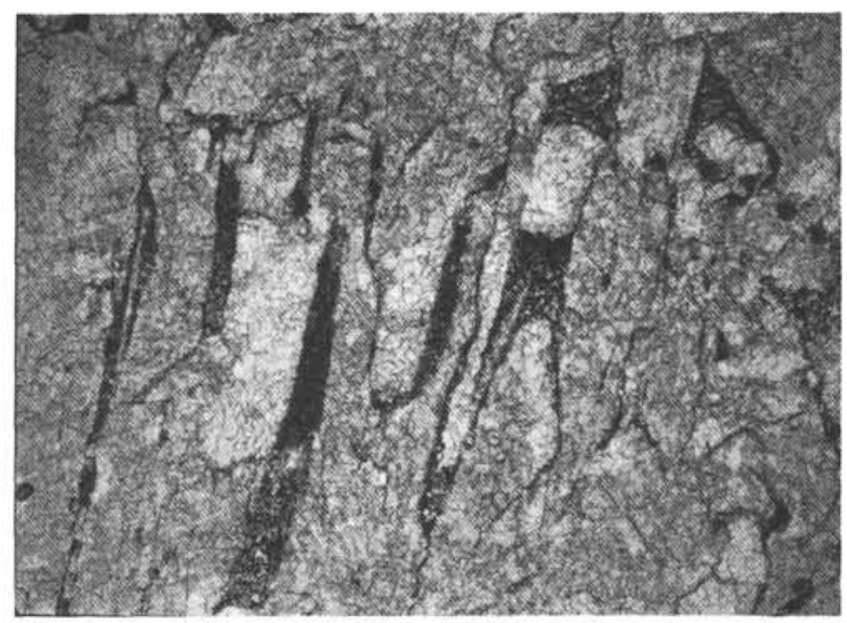

Figure 3. Microcrystalline carbonates with iron oxide partings (former nodular limestones?). Sample $654 \mathrm{~A}-48 \mathrm{R}-1,33-40 \mathrm{~cm}$, polarized light, $12 \mathrm{X}$. 


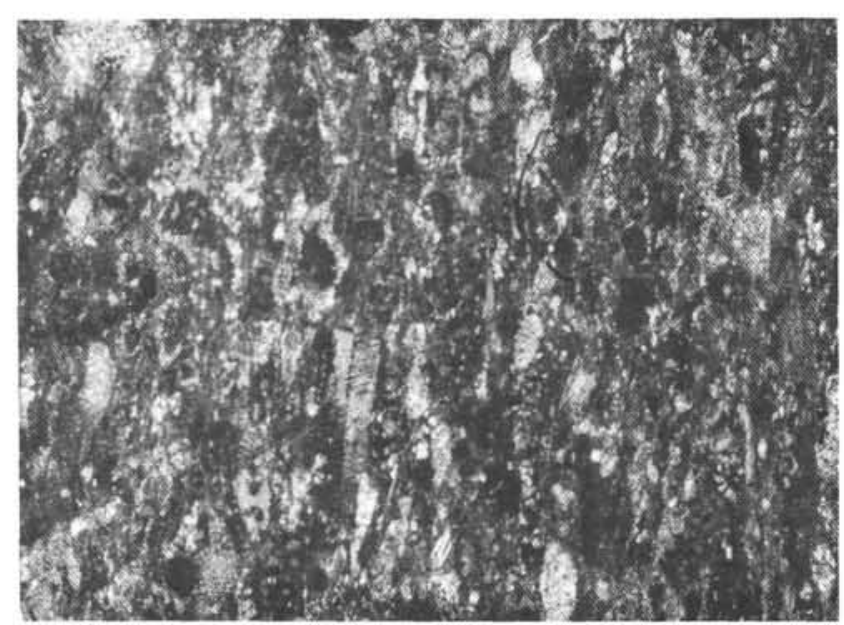

Figure 4. Biomicrite (with some microsparite) containing crinoids, brachiopods, and lower Triassic foraminifers. Sample 654A-50R-1, 78$80 \mathrm{~cm}$, polarized light, $42 \mathrm{X}$.

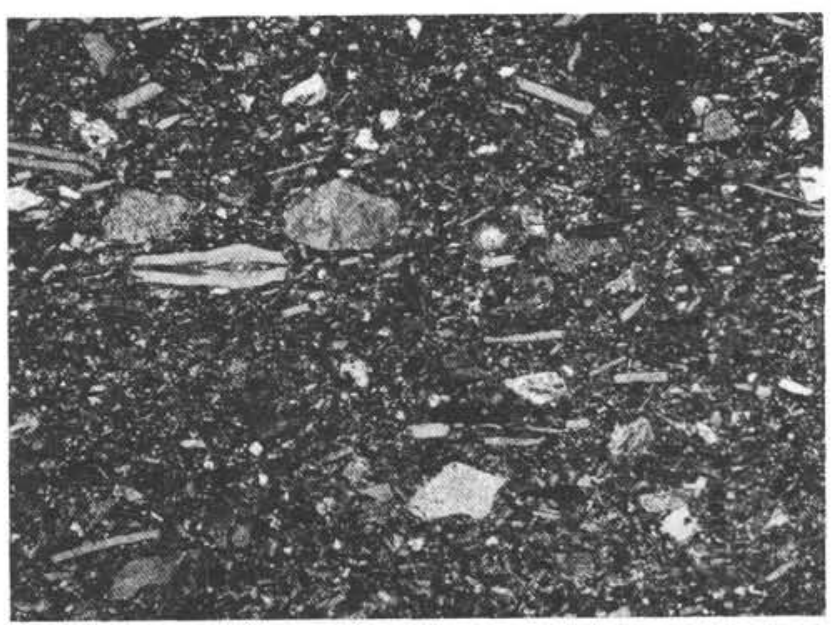

Figure 5. Greenish sandstones including Operculina fragments, lowgrade metamorphic rocks, crystals, etc. Sample $654 \mathrm{~A}-46 \mathrm{R}-1,50-53 \mathrm{~cm}$, polarized light, 10X.

Table 1. Heavy mineral content. Abbreviations: $\mathbf{A m}=$ amphibole; $\mathbf{A n}=$ anhydrite; $\mathbf{A p}=$ apatite; $\mathbf{B i}=$ biotite; $\mathbf{C a}=\mathbf{c a r b o n a t e}(\mathbf{d o l o m i t e}) ; \mathbf{C h}=$ chlorite; $\mathbf{C d}=$ chloritoid $; \mathrm{Cp}=$ clinopyroxene; $\mathrm{Ep}=$ epidote; $\mathrm{Si}=$ sillimanite; $\mathbf{G a}=$ garnet (two different types); $\mathrm{Ma}=$ magnetite; $\mathrm{Mu}=$ muscovite; $\mathbf{M o}=$ monazite; $\mathbf{O p}=$ opaque minerals; $\mathbf{R u}=$ rutile; $\mathrm{St}=$ staurolite; $\mathrm{To}=$ tourmaline $\mathbf{Z r}=$ zircon. $\mathbf{A A}=$ abundant $\mathbf{A}=$ less abundant $; \mathbf{P}$ $=$ present $\mathbf{T}=$ trace; ? = doubtful; $\mathbf{A 2}=$ two types of garnet present.

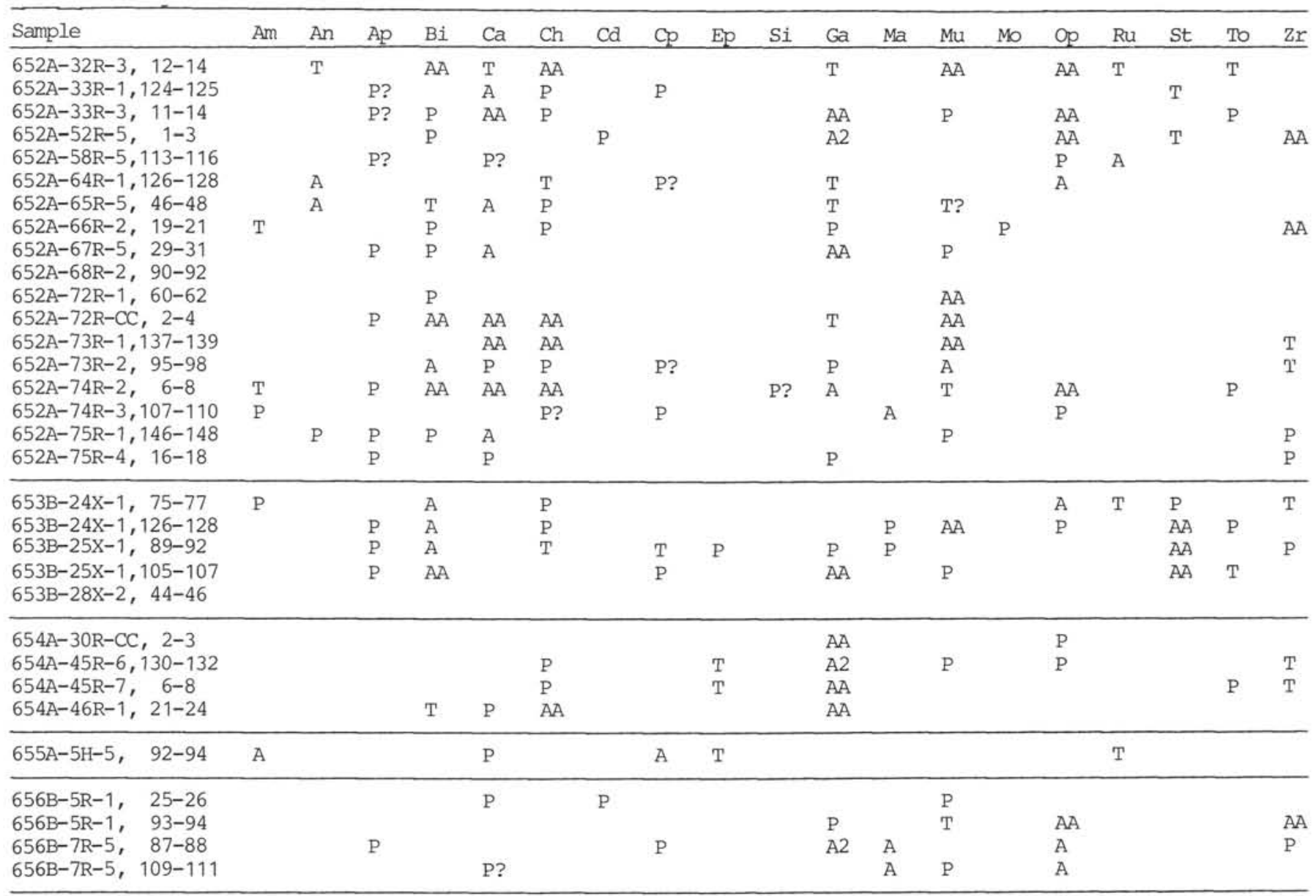


leozoic rocks of the Hercynian basement of Sardinia (Sartori et al., 1987). The presence of possible deep-water facies fits well with the Devonian sequences of that island. However, a provenance from the highest nappes of Calabria (Devonian metalimestones and quartz phyllites of the Stilo Unit; see Scandone, 1982) can not be completely excluded. The nonmetamorphic carbonate clasts represent the lower Triassic cover, in alpine facies, of a crystalline basement. They are equivalents to the clasts found inside the detrital Verrucano Formation in southern Tuscany (Cocozza et al., 1975).

The sand-sized elements and the heavy minerals of Unit 5 indicate a hinterland source area made mostly of low-grade metamorphic rocks, that can be easily referred to the crystalline sequences of a Hercynian basement.

\section{Site 653 (Cornaglia Terrace)}

At this site, drilling was made through the Pliocene-Pleistocene sequences and was terminated inside the uppermost Messinian intervals. Heavy minerals from clastic levels inside the evaporitic sequence in Hole 653 are characterized (Table 1) by the association of apatite, biotite, chlorite, garnet, and muscovite. Staurolite is also present, as well as clinopyroxene. This suite recalls again a source area made of crystalline rocks of various grades, referable to the Sardinia Hercynian basement, although the same minerals are found in the highest Calabrian nappes (Bonardi et al., 1984).

\section{Site 652 (lower Sardinia margin)}

This site was drilled on a tilted block east of the R. Selli Line, in an area with crustal thickness of less than $10 \mathrm{~km}$ (Recq et al., 1984). Rock fragments have been studied inside the inferred Messinian sequences from the arenites of Unit 5 and from a conglomerate interval at the base of Unit 4 (Kastens, Mascle, et al., 1987). Heavy mineral distribution has been examined from samples scattered throughout both units.

\section{Lithologic Unit 5}

It develops from $344.3 \mathrm{mbsf}$ to the bottom of the hole (721.1 mbsf) (Cores 37R-75R) and includes arenitic layers whose frequency and coarseness increase downward (namely from some 684 to $721.1 \mathrm{mbsf}$ ). Sand-sized grains are mostly siliciclastic, made by low-grade metamorphic rocks, but abundant carbonate lithoclasts occur mainly in the lowermost cores. The latter are mainly micritic limestones sometimes containing tintinnid tests of Late Jurassic-Early Cretaceous age, and some isolated planktonic foraminifers of Paleogene age (Morozovella) (Borsetti et al., this volume).

\section{Conglomerate at Bottom of Unit 4}

The conglomerate occupies Core $36 \mathrm{R}$ from some 335 to 344.3 mbsf, although downhole measurements suggest that the coarse interval could be as thick as $15 \mathrm{~m}$ (Kastens, Mascle, et al., 1987). Only 14 pebbles, up to $8 \mathrm{~cm}$ long, were recovered. Their lithology will be described in detail since they give indications on the nature of the basement in the vicinity of the area.

The most abundant lithotypes (six specimens) are biomicrites with abundant calcitized radiolarians (Fig. 6A) and with rare planktonic foraminifers including Hedbergella (Fig. 6B). These rocks indicate an open marine environment spanning from possible Late Jurassic to Middle Cretaceous age.

One sample is a packstone made by fragments of Rudistae, green algae, benthic foraminifers, mollusks, in a minor matrix containing angular quartz grains, rare ostracodes, and planktonic foraminifers (Fig. 7). A deep-water environment or a scarp close to a productive rudistid carbonate platform is indicated; the age is Upper Cretaceous.

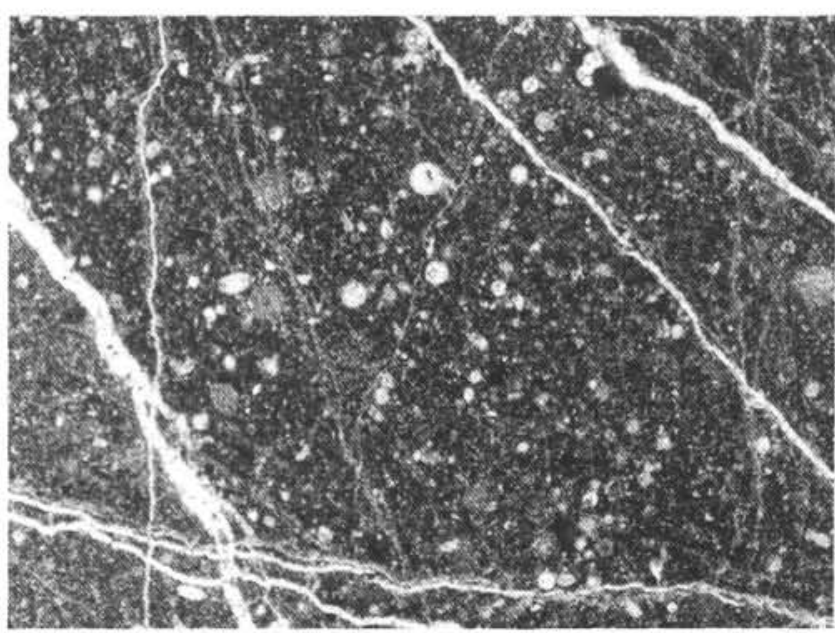

A

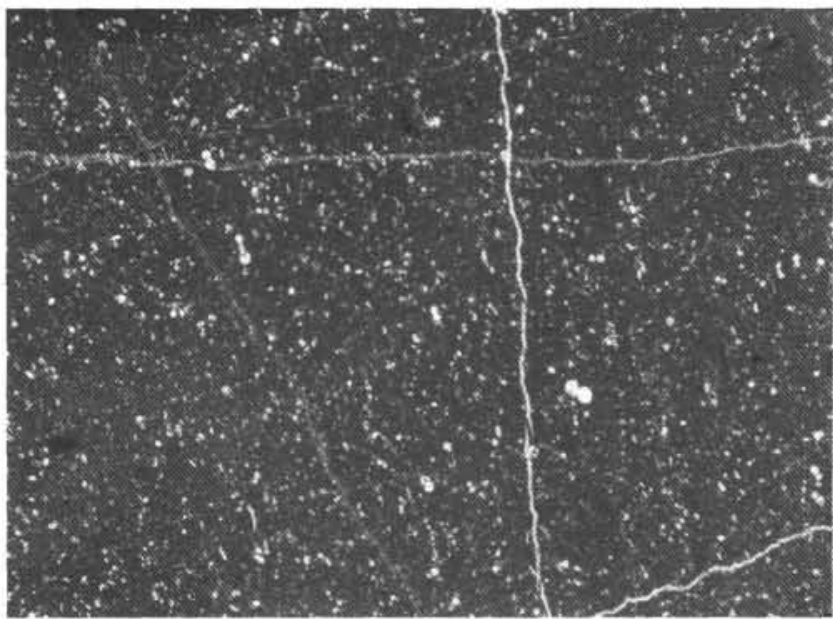

B

Figure 6. A. Radiolarian-bearing mudstone. B. Planktonic foraminiferbearing mudstone. Late Jurassic to Middle-Upper Cretaceous age. Samples $652 \mathrm{~A}-36 \mathrm{R}-\mathrm{CC}, 1-10 \mathrm{~cm}$, clast no. 6 (A); clast no. 9 (B), polarized light, 27X.

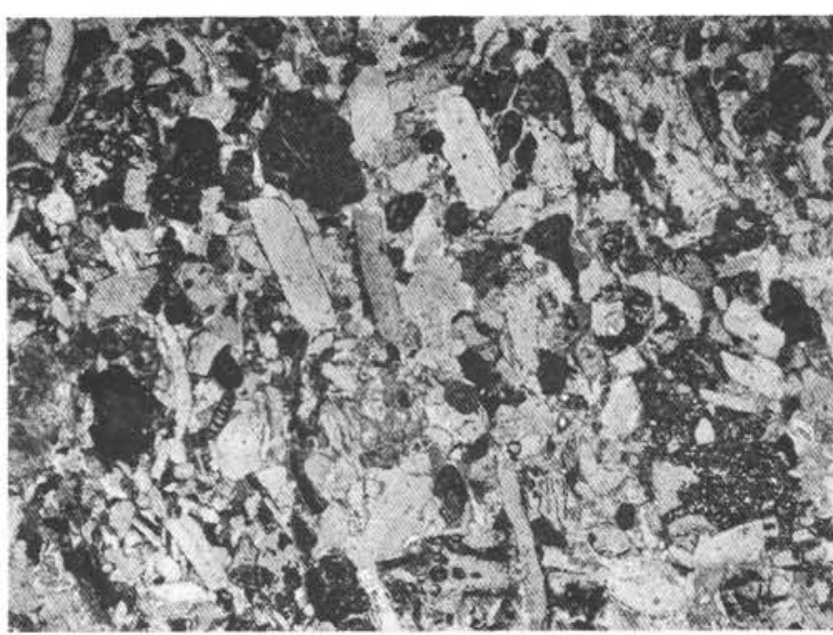

Figure 7. Packstone with Rudistae fragments (large white pieces), algae, benthic foraminifers, Upper Cretaceous. Sample 652A-36R-CC, 1-10 $\mathrm{cm}$, clast no. 5 , polarized light, $12 \mathrm{X}$. 
Another sample is a grainstone containing large benthic foraminifers, bryozoa, red algae, echinid plates, mollusk fragments and rare planktonic foraminifers (Fig. 8), with scarce spar cement. The sample indicates a shallow-marine (less than 100-150 $\mathrm{m})$, high-energy bank of Paleogene to possibly lower Miocene age.

Two specimens are polymictic sandstones with angular grains of metamorphic and igneous quartz, of calcite, dolomite, lowgrade metamorphic rocks, possible igneous rocks, glauconite, very rare bryozoa, mollusk fragments, and benthic foraminifers (Fig. 9). This represents a postorogenic nonmature deposit whose age can tentatively be assumed as lower-middle Miocene by comparison with the surrounding regions (see below).

Two other samples are a quartzarenite made by well-rounded grains in a spar cement and a calcareous phyllite of very low metamorphic grade, both of unspecifiable age.

\section{Heavy Minerals}

There are no major differences in heavy mineral distribution throughout Units 5 and 4 (Table 1). The suites are characterized by apatite, biotite, chlorite, garnet, and muscovite, plus anhydrite and dolomite that characterize the Messinian evaporitic sequences. Scattered staurolite, chloritoid, and clinopyroxene recall the suites of Site 653. Sillimanite possibly occurs in sample $652-74 \mathrm{R}-2,6-8 \mathrm{~cm}$ (702.48 mbsf), which suggests a source of metamorphic rocks of Barrovian type during Messinian.

\section{Source of Rock Clasts and of Heavy Minerals}

There is a major difference with the previous sites since clast petrography suggests a source made by Mesozoic to Tertiary carbonate pelagic sequences perhaps including "Helmintoides"type carbonate flysch. This latter lithotype could have persisted with poor lithification for a long time, releasing the isolated Morozovella tests of Paleogene age (Borsetti et al., this volume). The whole carbonate sequence is very similar to the ones constituting tectonic units in the southern Apennines and in the Maghrebian chain of Sicily (Catalano et al., 1976). The terrigenous Tertiary clasts might be correlated to postorogenic deposits (glauconitic calcarenites) covering tectonic units of basement in Calabria (Amodio-Morelli et al., 1976; Grandjacquet and Mascle, 1978).

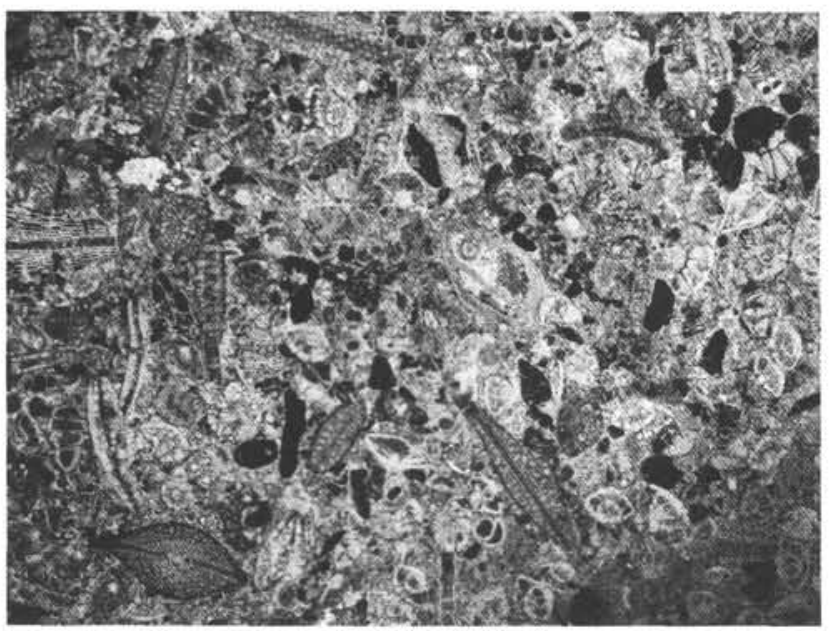

Figure 8. Grainstone including Lepidocyclinae, Operculinae, Amphisteginae, bryozoans, mollusk fragments, red algae, and rare planktonic foraminifers. Oligocene-lower Miocene, Sample 652A-36R-CC, 1-10 $\mathrm{cm}$, clast no. 1 , polarized light, $10 \mathrm{X}$.

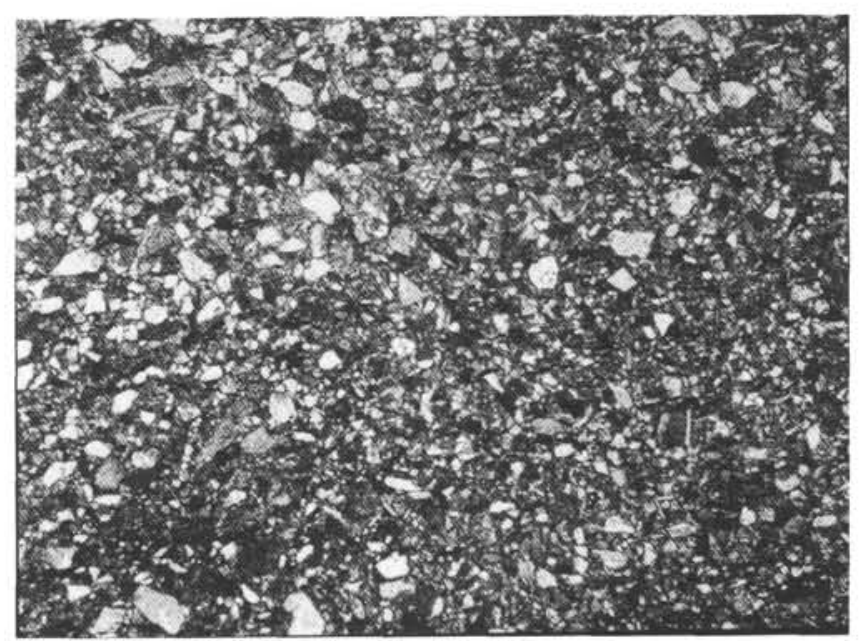

Figure 9. Polymictic sandstone, Miocene?. Sample 652A-36R-CC, 1-10 $\mathrm{cm}$, clast no. 10 , polarized light, $20 \mathrm{X}$.

Basement of high metamorphic grade is notably absent in the rock samples of the site, although heavy minerals give a suite which is not drastically different from the ones of the previous sites. The occurrence of possible sillimanite may indicate the proximity of a Barrovian belt. This could be related to the Sardinia basement to the west, but also to the tectonic units of basement making up parts of the Calabrian Arc (Scandone, 1982). Sillimanite-bearing basement pertinent to Calabride units has already been reported by Dal Piaz et al. (1983) for the Flavio Gioia Seamount, which is close to the site and had to be even closer in Messinian, prior to emplacement of oceanic crust in the Vavilov Basin.

The De Marchi Seamount is the relief closest to the site. Its lithologies (Colantoni et al., 1981; Gennesseaux et al., 1986; see also Site (56) are however quite different from the ones recovered in Site 652. This suggests the following considerations:

1. The acoustic basement in the area around Site 652 has to be quite complex and different from block to block;

2. Basement characters recall those of tectonic units making up various segments of the southern Apenninic, Calabrian, and Sicilian chains;

3. These basement characters are the rule east of the R. Selli Line; moving west, we pass instead to a Hercynian basement of Sardinia type (see the maps in Sartori, 1986; Sartori et al., 1987).

\section{Site 656 (lower Sardinia margin)}

Two holes, 656A and 656B, were drilled a few miles south of Site 652 , on the western flank of the De Marchi Seamount. This is the last tilted block at the boundary with the oceanic crust (Kastens, Mascle, et al., 1987). It has been extensively sampled in the past by dredgings and submersible divings (Colantoni et al., 1981; Gennesseaux et al., 1986) and has yielded a variety of lithologies indicative of the presence of Liguride ophiolite nappes and of other units of the Alpine/Apenninic domains.

Unit 4, 179.1-236.4 mbsf in Hole 656A, and 105.6-121.8 mbsf in Hole 656B, contains the lowermost drilled sequences made by pre-Pliocene (Messinian?) conglomerates. Pebbles and cobbles are contained in a very bright and deep red dolomitic matrix and represent a continental deposit deriving from erosion of the De Marchi Seamount. 


\section{Conglomerates of Unit 4}

The main observed lithologies are deeply altered metamorphic rocks and scarce sedimentary rocks; some clusters of diagenetic iron oxides/hydroxides also occur. The latter shall, however, not be dealt with in this chapter.

\section{Metamorphic Rocks}

\section{Metabasites}

Such lithotypes are the most abundant among the clasts, appearing macroscopically as greenstones, metagabbros, and metadolerites, often deeply altered and substituted by large clusters of fibrous amphibole crystals (Fig. 10). Some of them appear foliated. In thin sections parallel to the foliation planes, the observed textures are equant with large granonematoblastic crystals or fibro-radial aggregates of actinolite-tremolite which developed around small clear amphibole prisms. Palimpsest textures are not frequent, either volcanic or doleritic. No relics of original ferromagnesian phases are observed, except for some rare examples of zoned crystals of amphibole replacing previous pyroxene. The paragenesis is dominated by actinolite, which is prismatic, colorless to pale yellow, sometimes pale green. The existence of fibro-radial aggregates around a single prism suggests a multiphase growing. Small calcosodic feldspars (albite) appear between the amphibole prisms; they are often muscovitized and sometimes replaced by zoisite. Calcite appears as large granoblastic crystals including actinolite and casting the amphibole aggregates. A later generation of calcite often replaces totally or partially the albite and actinolite crystals. Chlorite (magnesiochlorite) shows small fibro-radial aggregates associated with the first generation calcite or at the boundary of actinolite crystals. Sphene (leucoxene) is locally abundant in association with the first generation calcite. Small xenomorph crystals are either isolated or form coronites around iron-titanium oxides, exceptionally around rutile. Zoisite has been observed in few thin sections in prismatic crystals inside albite. The paragenesis belongs to the greenschist facies (s.1.) and is similar to the one well known in the Alpine ophiolites, for example in Mongénevre area, and in the Liguride ophiolites of the Apennines.

\section{Metasediments}

Macroscopically, the metasediments are red and white cherts, impure metalimestones or phyllite-marble alternations. In thin section, cherts contain several recrystallized globules and fragments of quartz, possibly former radiolarians (Fig. 11). Such lithotypes may be referred to the "Diaspri" cherts covering the ophiolites of the Mesozoic Tethyan domain.

The impure metalimestones contain carbonate levels of blocky sparite alternated with phyllitic layers, or are impure marbles with scattered metamorphic quartz and feldspar. Some of these lithotypes may recall the so-called "Palombini shales," turbidites of the Mesozoic cover of Liguride ophiolites.

\section{Sedimentary Rocks}

\section{Sedimentary rock types are:}

1. Homogeneous micrites containing silt- to sand-sized crystals and angular fragments of quartz. Pyrite and carbonaceous frustules are also present, together with rare possible glauconite and problematic biogenic remains (annelids?; oogons?).

2 . Impure arenites with quartz and micrite fragments, dolomite crystals, and rare problematic biogenic remains (Fig. 12).

3. Fine quartzarenites with matrix rich in sulfides, rare blue and green pleochroic small crystals (amphiboles?).

4. Very fine and barren micrite.

Such lithotypes are hardly definable in terms of age and structural pertinence. They may recall postorogenic deposits covering the Alpine nappes of Calabria.

\section{Heavy Minerals}

The samples from Hole 656B exhibit an association made by two garnets, chlorite, zircon, and opaques (Table 1); the garnets are mainly brown-colored. High-grade minerals, like blue amphiboles apparently observed in smear slides of Quaternary surrounding sediments (Kastens, Mascle, et al., 1987), are not present.

\section{Source of Rock Clasts and of Heavy Minerals}

The clasts clearly derive from Ligurian-type ophiolitic units, including metabasites and their Mesozoic cover metamorphosed in the greenschist facies. Sedimentary rocks may represent preTortonian postorogenic deposits. The source area is the basement of the nearby De Marchi Seamount, where ophiolitic units are well represented (Colantoni et al., 1981), together with other lithotypes not encountered in the Holes. Again, the basement of the very thin lower Sardinia margin contains a complex nappe suite of the Alpine/Apenninic orogenic systems.

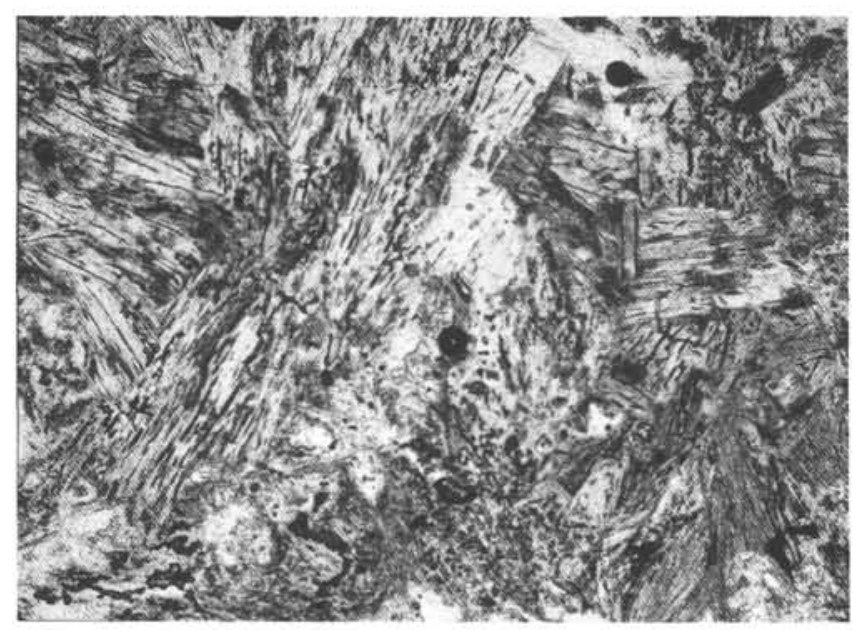

Figure 10. Clusters of fibrous-radial amphibole crystals on metabasites. Sample 656B-6R-1, 20-22 cm, polarized light, 27X.

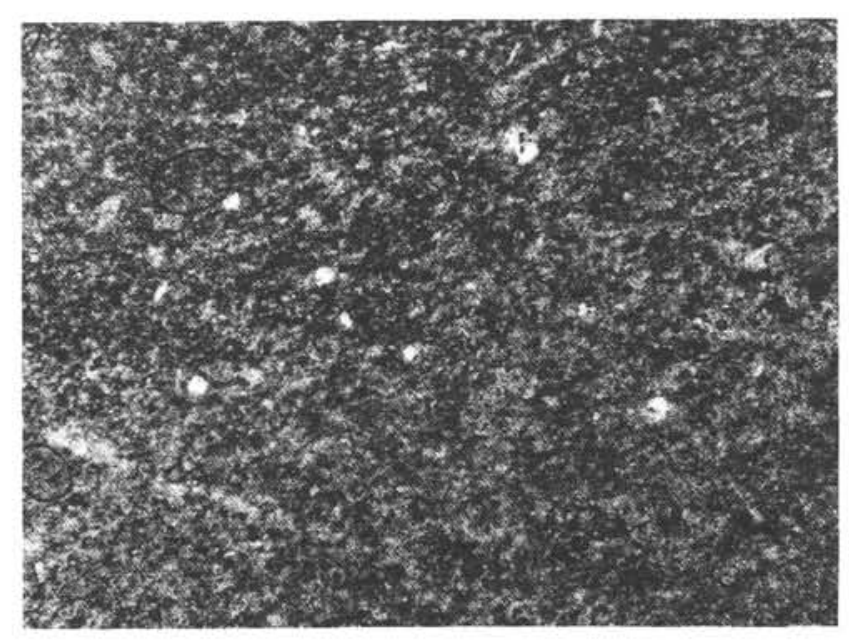

Figure 11. Recrystallized radiolarians in chert. Sample 656A-9R-4, 88$89 \mathrm{~cm}$, polarized light, $25 \mathrm{X}$. 


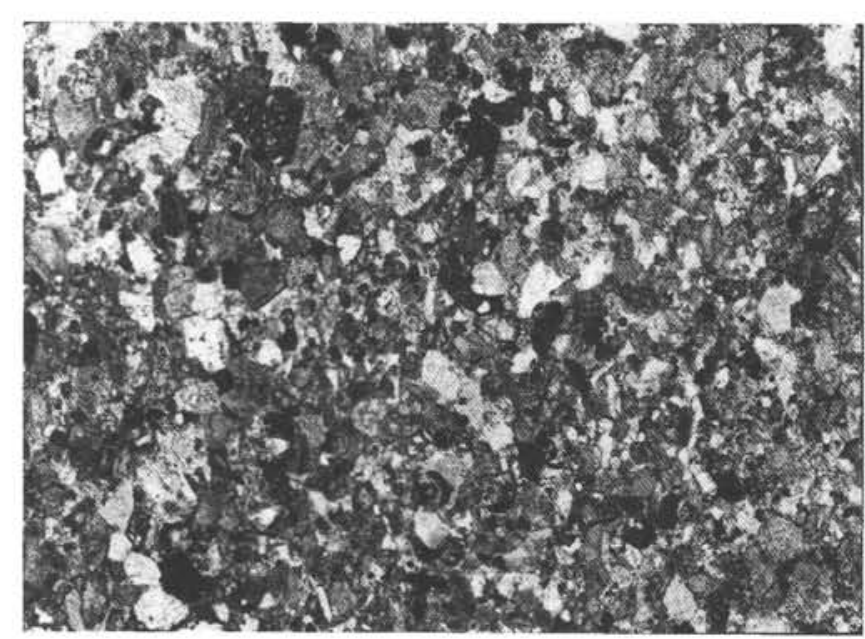

Figure 12. Impure arenites with quartz and micrite fragments, dolomite crystals and rare biogenic remains. Sample $656 \mathrm{~A}-11 \mathrm{R}-1,20-22 \mathrm{~cm}$, polarized light, $27 \mathrm{X}$.

\section{CONCLUSIONS}

The previous observations and the already available sampling data set (Sartori et al., 1987) suggest that the acoustic basement of the east Sardinia continental margin is made by pre-upper Tortonian units stretched during formation of the Tyrrhenian Basin.

The basement of the upper Sardinia margin and of the Cornaglia Terrace (Sites 654, 653), where crustal thinning is not severe (some $20 \mathrm{~km}$ in Recq et al., 1984), mostly contains Paleozoic rocks referable to a Hercynian basement with its cover. It can then be the analogous to the one representing the alpine foreland in Sardinia and in western Corsica. However, the possible Calabrian affinity of some clasts, and the Tuscan affinity of the nonmetamorphic clasts at Site 654 , together with the findings of ophiolites at the Baronie Seamount (see the map in Sartori, 1986), suggest that the Hercynian basement of Sardiniatype does not extend very much eastward in the northern Tyrrhenian Sea.

Its extension could be wider still in the vicinity of the R. Selli Line, along the southern portion of the Sardinia margin (Sartori, 1986). Close and east of that line, a marked crustal thinning occurs (8-10 km, according to Recq et al., 1984) and the basement contains units of the Alpine/Apenninic chains (Sites $652,656)$, such as those making up the backbone of peninsular Italy and of Sicily, piled up prior to the upper Tortonian start of basin stretching (Sartori, 1986).

If we assume that such recently orogenized areas had a crust thicker than the "normal" cratonic one of Sardinia alpine foreland prior to stretching, we are forced to infer that the maximum thinning was experienced by orogenic domains formed in
Cretaceous through middle Tortonian phases. The thinning was then very rapid and very strong and, unlike in the western Mediterranean Basin, affected a recently orogenized, and thickened, domain.

\section{REFERENCES}

Amodio-Morelli, L., Bonardi, G., Colonna, V., Dietrich, D., Giunta, G., Ippolito, F., Liguori, V., Lorenzoni, S., Paglionico, A., Perrone, V., Piccaretta, G., Russo, M., Scandone, P., Zanettin-Lorenzoni, E., and Zuppetta, A., 1976. L'arco Calabro-Peloritano nell'orogene Appenninico-maghrebide. Mem. Soc. Geol. It., 17:1-60.

Bonardi, G., Compagnoni, R., Messina, A., and Perrone, V., 1984. Riequilibrazioni metamorfiche di probabile eta alpina nell'unita dell'Aspromonte. Arco Calabro Peloritano. Rend. Soc. It. Mineral. Petrol., 39:613-628.

Catalano, R., Channell, J.E.T., D'Argenio, B., and Napoleone, G., 1976. Mesozoic paleogeography of the Southern Apennines and Sicily. In Pialli, G. (Ed.), Palaeomagnetic stratigraphy of pelagic carbonate sediments. Mem. Soc. Geol. It., 15:95-118.

Cocozza, T., Lazzarotto, A., and Pasini, M., 1975. Segnalazione di una fauna triassica nel conglomerato di $\mathrm{M}$. Quoio (Verrucano del Torrente Farma, Toscana Meridionale). Riv. It. Paleontol. Stratigr., 81: $425-430$.

Colantoni, P., Fabbri, A., Gallignani, P., Sartori, R., and Rehault, J. P., 1981. Carta Litologica e Stratigrafica dei Mari Italiani, Scala 1/1.500.000. Litogr. Artistica Cartografica, Firenze.

Dal Piaz, G. V., Del Moro, A., Di Sabatino, B., Sartori, R., and Savelli, C., 1983. Geologia del M. Flavio Gioia (Tirreno centrale). Mem. Sci. Geol. Padova, 35:429-452.

Gennesseaux, M., Rehault, J. P., Thomas, B., Colantoni, P., Fabbri, A., Lepvrier, C., Mascle, G., Mauffret, A., Polino, R., Robin, C., and Vanney, J. R., 1986. Resultats des plongées en submersible Cyana sur les blocs continentaux basculés et le Volcan Vavilov (mer Tyrrhenienne centrale). C. R. Acad. Sci. Paris, 302/12:785-792.

Grandjacquet, C., and Mascle, G., 1979. The structure of the Ionian Sea, Sicily and Calabria-Lucania. In Nairn, A.E.M. et al. (Eds), The Ocean Basins and Margins, 4B, New York (Plenum), 257329.

Kastens, K., Mascle, J., et al., 1987. Proc. ODP, Init. Repts, 107: College Station, TX (Ocean Drilling Program).

Mascle, G., Sartori, R., and ODP Leg 107 Scientific Staff, 1986. Nature du substratum de la marge sarde: resultats des forages de la campagne 107 du JOIDES Resolution (Ocean Drilling Program). 30th Congr. CIESMM, Palma de Majorca, 20-25 Oct. 1986 (Abstract).

Recq, M., Rehault, J. P., Steinmetz, L., and Fabbri, A., 1984. Amincissement de la croute et accretion au centre du bassin Tyrrhenien d'aprés la sismique refraction. Mar. Geol., 55:411-428.

Sartori, R., 1986. Notes on the geology of the acoustic basement in the Tyrrhenian Sea. Mem. Soc. Geol. It., 36:99-108.

Sartori, R., Mascle, G., and Amaudric du Chaffaut, S., 1987. A review of circum tyrrhenian regional geology. In Kastens, K., Mascle, J., et al., Proc. ODP, Init. Repts, 107:College Station, TX (Ocean Drilling Program), 37-63.

Scandone, P., 1982. Structure and evolution of the Calabrian Arc. Earth Evol. Sci., 3:172-180.

Date of initial receipt: 29 June 1988

Date of acceptance: 17 January 1989

Ms 107B-136 